\title{
Fuzzy-Based Screening System for Determination of Enhanced Oil Recovery (Eor) Method in Reservoir
}

\author{
Nesi Syafitri $^{1}$, Tomi Erfando ${ }^{2}$, Widya Lestari ${ }^{3}$, Niken Karina Rinaldi ${ }^{4}$ \\ Departement of Informatics Engineering, Universitas Islam Riau ${ }^{1}$ \\ Department of Petroleum Engineering, Universitasi Islam Riau ${ }^{2,3,4}$ \\ nesi.syafitri@eng.uir.ac.id, tomierfando@eng.uir.ac.id, widya@ student.uir.ac.id, \\ niken@student.uir.ac.id
}

\begin{tabular}{l}
\hline Article Info \\
\hline Article history: \\
Received Okt 27, 2021 \\
Revised Dec 21, 2021 \\
Accepted Jan 12, 2022
\end{tabular}

Keyword:

Petroleum

Industry

EOR method

Fuzzy

Sensitivity

\begin{abstract}
The petroleum industry is developing technology to increase oil recovery in reservoirs. One of the technologies used is Enhanced Oil Recovery (EOR). Selecting an EOR method for a specific reservoir condition is one of the most challenging tasks for a reservoir engineer. This study tries to build a fuzzy logic-based screening system to determine the EOR method. It created the system intending to assist in selecting and determining the appropriate EOR method used in the field. There are nine input criteria used to screen the EOR criteria: API Gravity, Oil Saturation, Formation Type, Net Thickness, Viscosity, Permeability, Temperature, Porosity, Depth criteria. The output criteria generated from the calculation of the EOR screening criteria are 14 outputs, namely: $\mathrm{CO} 2 \mathrm{MF}$ Miscible Flooding, $\mathrm{CO} 2$ IMMF Immiscible Flooding, HC MF Miscible Flooding, HC IMMF Immiscible Flooding, N2 MF Miscible Flooding, N2 IMMF Immiscible Flooding, WAG MF Miscible Flooding, HC+WAG IMMF Immiscible Flooding, Polymer, ASP, Combustion, Steam, Hot Water, Microbial. In this system, 512 rules are generated to produce 14 different outputs of the EOR method, with Mamdani's Fuzzy Inference reasoning. This fuzzy-based screening system has an accuracy rate of $80.95 \%$, so this system is suitable to assist reservoir engineers in determining the appropriate EOR method to be used according to the conditions in the reservoir. The sensitivity level of the system only reaches $53.1 \%$, while the specificity level reaches $94 \%$.
\end{abstract}

(C) This work is licensed under a Creative Commons AttributionShareAlike 4.0 International License.

Corresponding Author:

Nesi Syafitri

Departement of Informatics Engineering

Universitas Islam Riau

JL. Kaharuddin Nasution No.113, Pekanbaru, Riau

Email: nesisyafitri@eng.uir.ac.id

\section{INTRODUCTION}

Currently, the oil industry is developing technology to increase oil recovery in reservoirs. According to Aladasani[1]-[3], increasing oil recovery is presently focusing on research and development of the proper Enhanced Oil recovery method in a field. Screening Criteria can be used as a guide or the first step in implementing Enhanced Oil Recovery (EOR). If the Screening 
Criteria are successfully implemented, selecting the following stage method becomes easier [4][6].

Screening Criteria is a step to identify known parameters of a reservoir. Meanwhile, Enhanced Oil Recovery is a method used to increase the recovery of oil reserves[7]-[12]. Of the 15 parameters that exist in the EOR Screening Criteria such as: API Gravity, Oil Saturation, Formation Type, Net Thickness, Viscosity, Permeability, Temperature, Salinity, Depth, and so on, a minimum of two parameters is required to determine the method in Enhanced Oil Recovery (EOR). Namely, the degree of API and reservoir depth [13]-[15].

Based on these problems, this research will build an EOR filtering system based on fuzzy logic that can help and simplify reservoir work carried out by reservoir engineers or students in the oil sector in determining the EOR method suitable for use in a reservoir.

In the screening system to be built, nine input criteria will be used to screen EOR criteria, namely: API Gravity, Oil Saturation, Formation Type, Net Thickness, Viscosity, Permeability, Temperature, Porosity, Depth criteria.

Nageh conducted similar research, Mohamed. et al., regarding applications using fuzzy logic on the screening criteria of EOR technology. Screening tool developed with Matlab programming language[16]-[19].

\section{RESEARCH METHOD}

According to Trujilo [14], the filtering criteria is the step of identifying the known parameters of a reservoir. Meanwhile, Enhanced Oil Recovery (EOR) is a method used to increase the recovery of oil reserves based on the input and output parameters produced. Table 1 describes the units used for each parameter[20], [21].

Table 1. Input parameters and units used

\begin{tabular}{cll}
\hline No & \multicolumn{1}{c}{ Parameters } & \multicolumn{1}{c}{ Units } \\
\hline 1 & API Gravity $\left({ }^{0} \mathrm{API}\right)$ & Derajat Gravity \\
\hline 2 & Oil Saturation $(\%)$ & Percent \\
\hline 3 & Formation Type $(\mathrm{SC}$ & Sandstone and Carbonate \\
\hline 4 & Net Thickness $(\mathrm{ft})$ & Feet \\
\hline 5 & Viscosity $(\mathrm{Cp})$ & Centipose \\
\hline 6 & Permeability $(\mathrm{mD})$ & Mili darcy \\
\hline 7 & Temperature ${ }^{0} \mathrm{~F}$ & Derajat Fahrenheit \\
\hline 8 & Porosity $(\%)$ & Percent \\
\hline 9 & Depth $(\mathrm{ft})$ & Feet \\
\hline
\end{tabular}

The domain set of each input parameter used to screen the EOR criteria is as follows:

1. API Gravity Criteria (0-60), consisting of Low (0-20), Medium (5-60), and High (40-60)

2. Oil Saturation Criteria (0-1), consisting of Low (0-0.6), Medium (0.4-1), and High (0.8-1)

3. Formation Type Criteria (0-18), consisting of Sandstone (0-5), Sorc (2-18), and Carbonate (10-18)

4. Net Thickness Criteria (0-20), consisting of Thin (0-10), NC (5-20), and Width (15-20)

5. Viscosity Criteria (0.0001-100000), consisting of Low (0.0001-1000), Medium (1-10000), and High (5000-10000)

6. Permeability criteria, consisting of Low (0-100), Medium (10-100000), and High (10000100000)

7. Temperature Criteria (0-400), consisting of Low (0-200), Medium (100-400), and High (300-400)

8. Criteria for porosity (0-70), consisting of Low (0-30), Medium (10-70), and High (50-70)

9. Depth Criteria (0-20,000), consisting of Low (0-10000), Medium (5000-20000), and High (15000-20000) 
The set of output criteria domains resulting from the calculation of the EOR filtering criteria is as follows:

1. Criteria for Miscible Flooding MF CO2 (0-100), consisting of Unsuitable (0-60), Eligible (40-100), and Very Eligible (80-100)

2. MMF CO2 Flooding Immiscible Criteria (0-100), consisting of Unsuitable (0-60), Eligible (40-100), and Very Eligible (80-100)

3. Criteria for Miscible Flooding HC MF (0-100), consisting of Inappropriate (0-60), Eligible (40-100), and Very Eligible (80-100)

4. Criteria for Immiscible Flooding HM IMMF (0-100), consisting of Not Eligible (0-60), Eligible (40-100), and Very Eligible (80-100)

5. Criteria N2 MF Miscible Flooding (0-100), consisting of Inappropriate (0-60), Eligible (40-100), and Very Eligible (80-100)

6. Criteria N2 IMMF Immiscible Flooding (0-100), consisting of Not Eligible (0-60), Eligible (40-100), and Very Eligible (80-100)

7. Criteria for WAG MF Miscible Flooding (0-100), consisting of Inappropriate (0-60), Eligible (40-100), and Very Eligible (80-100)

8. IMMF Immiscible Flooding Criteria HCTWAG (0-100), consisting of Not Eligible (0-60), Eligible (40-100), and Very Eligible (80-100)

9. Polymer Criteria (0-100), consisting of Inadequate (0-60), Eligible (40-100), and Very Eligible (80-100)

10. ASP Criteria (0-100), consisting of Not Eligible (0-60), Eligible (40-100), and Very Eligible (80-100)

11. Burning Criteria (0-100), consisting of Unfit (0-60), Eligible (40-100), and Very Eligible (80-100)

12. Steam criteria (0-100), consisting of Not Eligible (0-60), Eligible (40-100), and Very Eligible (80-100)

13. Criteria for Hot Water (0-100), consisting of Inappropriate (0-60), Decent (40-100), and Very Decent (80-100)

14. Microbial Criteria (0-100), consisting of Not Eligible (0-60), Eligible (40-100), and Very Eligible (80-100)

This fuzzy-based screening system consists of 9 (nine) fuzzy input parameters. Each input has 3 (three) fuzzy sets, as shown in table 2.

Table 2. Input Parameters with Fuzzy Set

\begin{tabular}{cll}
\hline No & \multicolumn{1}{c}{ Input parameter } & \multicolumn{1}{c}{ Fuzzy Set } \\
\hline 1 & API Gravity & Low, Medium, High \\
\hline 2 & Oil Saturation & Low, Medium, High \\
\hline 3 & Formation Type & Sandstone, Sorc, Carbonate \\
\hline 4 & Net Thickness & Thin, NC, wide \\
\hline 5 & Viscosity & Low, Medium, High \\
\hline 6 & Permeability & Low, Medium, High \\
\hline 7 & Temperature & Low, Medium, High \\
\hline 8 & Porosity & Low, Medium, High \\
\hline 9 & Depth & Low, Medium, High \\
\hline
\end{tabular}


The output of this system is the screening criteria of the EOR method, which consists of 14 categories. The number of fuzzy sets from each type consists of 3 (three) groups, as shown in table 3 .

Table 3. Output Parameters with Fuzzy Set

\begin{tabular}{|c|c|c|}
\hline No & Output Parameters & Fuzzy Set \\
\hline 1 & $\mathrm{CO}_{2} \mathrm{MF}$ & Not Eligible, Decent, Very Decent \\
\hline 2 & $\mathrm{CO}_{2} \mathrm{IMMF}$ & Not Eligible, Decent, Very Decent \\
\hline 3 & $\mathrm{HC} \mathrm{MF}$ & Not Eligible, Decent, Very Decent \\
\hline 4 & HM IMMF & Not Eligible, Decent, Very Decent \\
\hline 5 & $\mathrm{~N}_{2} \mathrm{MF}$ & Not Eligible, Decent, Very Decent \\
\hline 6 & $\mathrm{~N}_{2} \mathrm{IMMF}$ & Not Eligible, Decent, Very Decent \\
\hline 7 & WAG MF & Not Eligible, Decent, Very Decent \\
\hline 8 & HCTWAG IMMF & Not Eligible, Decent, Very Decent \\
\hline 9 & Polymer & Not Eligible, Decent, Very Decent \\
\hline 10 & ASP & Not Eligible, Decent, Very Decent \\
\hline 11 & Combustion & Not Eligible, Decent, Very Decent \\
\hline 12 & Steam & Not Eligible, Decent, Very Decent \\
\hline 13 & Hot Water & Not Eligible, Decent, Very Decent \\
\hline 14 & Microbial & Not Eligible, Decent, Very Decent \\
\hline
\end{tabular}

a. API Gravity

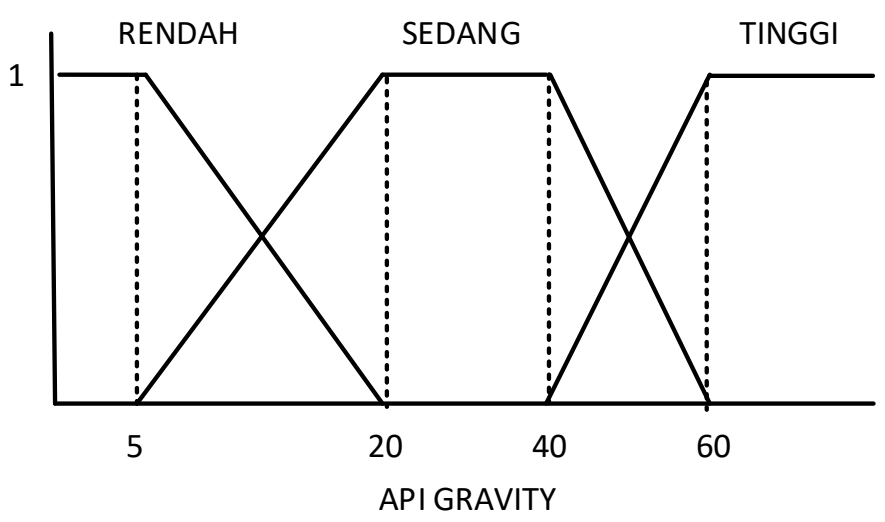

Fig 1. Membership Functions of the Gravity API

The Gravity API has 3 (three) fuzzy sets, namely: low, medium, and high groups with different domains, as shown in Figure 1. The membership functions of the three fuzzy sets are as follows: 
Fuzzy Set $=$ Low

$\mu_{\text {API_low }}[x]=\left\{\begin{array}{c}1 ; x \leq 5 \\ \frac{20-x}{15} ; 5 \leq x \leq 20 \\ 0 ; x \geq 20\end{array}\right.$

\section{Fuzzy Set $=$ Medium}

$\mu_{\text {API_Medium }}[x]=\left\{\begin{array}{c}0 ; x \leq 5 \text { or } x \geq 60 \\ \frac{x-5}{15} ; 5 \leq x \leq 20 \\ \frac{60-x}{20} ; 40 \leq x \leq 60 \\ 1 ; 20 \leq x \leq 40\end{array}\right.$

\section{Fuzzy Set $=$ HIgh}

$\mu_{\text {API_High }}[x]=\left\{\begin{array}{c}0 ; x \leq 5 \\ \frac{x-40}{20} ; 40 \leq x \leq 60 \\ 1 ; x \geq 60\end{array}\right.$

\section{RESULTS AND ANALYSIS}

System capability testing in determining the EOR method will be carried out with 65 test data obtained from several research sources, namely:

Table 4. Testing Data from several research sources

\begin{tabular}{clc}
\hline Experiment & \multicolumn{1}{c}{ Data Source } & Amount of Test Data \\
\hline 1 & $\begin{array}{l}\text { Research by P Sang Kang and J (2014) from the Korea } \\
\text { Maritime State in the Brashear and Kuuskraa fields }\end{array}$ & 10 \\
\hline 2 & $\begin{array}{l}\text { Research by Nageh (2015) from the State of Egypt, namely } \\
\text { the City of Cairo in the Egyption field, }\end{array}$ & 70 \\
\hline 3 & $\begin{array}{l}\text { Saleh's research (2014) from the United States of America, } \\
\text { namely the City of Columbia in the Carcoana field and its } \\
\text { surroundings }\end{array}$ & 7 \\
\hline 4 & $\begin{array}{l}\text { Hartono's research (2017) from Indonesia in several fields, } \\
\text { namely Tempino Kenali Asam, Duri, Minas, Ledok, } \\
\text { Klamono, and Handil }\end{array}$ & 4 \\
\hline 5 & $\begin{array}{l}\text { Research by Alvarado (2002) from the State of Indonesia in } \\
\text { the Handil field. }\end{array}$ & 7 \\
\hline
\end{tabular}


Table 5 shows the results of comparing outputs between those generated from the fuzzybased EOR screening system and the actual data from the research conducted by P Sang Kang and J (2014) shown in Maritime Korea, Brashear, and Kuuskraa fields.

Table 5. Comparison of Actual Data with System Prediction Results in Experiment 1

\begin{tabular}{|c|c|c|c|c|c|c|c|c|c|c|c|}
\hline \multirow{3}{*}{$\begin{array}{l}\text { Case } \\
\text { Data }\end{array}$} & \multicolumn{10}{|c|}{ Actual Data } & \multirow{3}{*}{$\begin{array}{c}\text { Sytem } \\
\text { Precition } \\
\text { Selected } \\
\text { EOR }\end{array}$} \\
\hline & \multicolumn{9}{|c|}{ Criteria } & \multirow{2}{*}{$\begin{array}{l}\text { EOR } \\
\text { Used }\end{array}$} & \\
\hline & $\begin{array}{c}\text { API } \\
\text { (Cp } \\
\text { ) }\end{array}$ & $\begin{array}{c}\text { Oil } \\
\text { Sat } \\
\text { urat } \\
\text { ion } \\
(\%)\end{array}$ & $\begin{array}{c}\text { For } \\
\text { mat } \\
\text { ion } \\
\text { Typ } \\
\text { e } \\
(\%)\end{array}$ & $\begin{array}{l}\text { Net } \\
\text { Thi } \\
\text { ckn } \\
\text { ess(f } \\
\text { t) }\end{array}$ & $\begin{array}{c}\text { Visc } \\
\text { osit } \\
\mathbf{y} \\
(\mathbf{C p} \\
)\end{array}$ & $\begin{array}{c}\text { Per } \\
\text { mea } \\
\text { bilit } \\
\mathbf{y} \\
(\mathbf{m d} \\
{ }^{2}\end{array}$ & $\begin{array}{c}\text { Temp } \\
\text { eratu } \\
\text { re } \\
\left({ }^{0} \mathrm{~F}\right)\end{array}$ & $\begin{array}{c}\text { Por } \\
\text { osit } \\
y \\
(\%)\end{array}$ & $\begin{array}{l}\text { Dept } \\
\text { h (ft) }\end{array}$ & & \\
\hline 1 & 26 & 25 & 1 & 5 & 20 & 4 & 200 & 20 & 4000 & $\mathrm{HC}$ MF & $\mathrm{HC} \mathrm{MF}$ \\
\hline 2 & 35 & 30 & 1 & 5 & 10 & 4 & 200 & 20 & 3937 & $\mathrm{HC}$ MF & HC MF \\
\hline 3 & 23 & 30 & 1 & 5 & 3 & 4 & 200 & 20 & 4000 & HC MF & $\mathrm{HC}$ MF \\
\hline 4 & 24 & 30 & 1 & 5 & 5 & 4 & 158 & 20 & 3937 & HC MF & HC MF \\
\hline 5 & 23 & 30 & 1 & 5 & 3 & 4 & 200 & 20 & 4000 & HC MF & HC MF \\
\hline 6 & 25 & 10 & 3 & 10 & 20 & 20 & 200 & 23 & 9000 & HC MF & HC MF \\
\hline 7 & 15 & 50 & 3 & 10 & 150 & 10 & 200 & 23 & 9000 & HC MF & HC MF \\
\hline 8 & 22 & 50 & 3 & 10 & 100 & 50 & 200 & 23 & 9000 & HC MF & HC MF \\
\hline 9 & 25 & 60 & 3 & 10 & 150 & 50 & 158 & 23 & 9000 & $\mathrm{HC}$ MF & $\mathrm{HC}$ MF \\
\hline 10 & 15 & 60 & 3 & 10 & 200 & 10 & 200 & 23 & 9000 & HC MF & $\mathrm{HC}$ MF \\
\hline
\end{tabular}

\section{CONCLUSION}

From the results of the design and manufacture of an intelligent application system based on Mamdani fuzzy logic, it can conclude that the accuracy of the screening system based on Mamdani fuzzy logic from 65 test data, only reached $80.95 \%$.

\section{ACKNOWLEDGEMENTS}

Thank you to the Islamic Universitas Islam Riau for funding this research so that we can achieve satisfactory results so that we can publish them properly.

\section{REFERENCES}

[1] E. Abbas and C. L. Song, "Artificial intelligence selection with capability of editing a new parameter for EOR screening criteria," J. Eng. Sci. Technol., vol. 6, no. 5, pp. 628-638, 2011.

[2] A. Aladasani and B. Bai, "Recent developments and updated screening criteria of enhanced oil recovery techniques," in International oil and gas conference and exhibition in China, 2010.

[3] V. Alvarado et al., "Selection of EOR/IOR opportunities based on machine learning," in European Petroleum Conference, 2002.

[4] E. M. E.-M. Shokir, H. M. Goda, M. H. Sayyouh, and K. A. Fattah, "Selection and evaluation EOR method using artificial intelligence," in Annual international conference and exhibition, 2002. 
[5] A. D. Hartono et al., "Revisiting EOR Projects in Indonesia through Integrated Study: EOR Screening, Predictive Model, and Optimisation," 2017.

[6] M. I. Hasan, "Pokok-pokok materi metodologi penelitian dan aplikasinya." Jakarta: Ghalia Indonesia, 2002.

[7] S. Kusumadewi, “Artificial intelligence (teknik dan aplikasinya)," Yogyakarta Graha Ilmu, vol. 5, 2003.

[8] P. Kang, J. Lim, and C. Huh, "Integrated screening criteria for offshore application of enhanced oil recovery," in SPE Annual Technical Conference and Exhibition, 2014.

[9] J.-Y. Lee, H.-J. Shin, and J.-S. Lim, "Selection and evaluation of enhanced oil recovery method using artificial neural network," Geosystem Eng., vol. 14, no. 4, pp. 157-164, 2011.

[10] M. Tarrahi, S. Afra, and I. Surovets, "A Novel Automated and Probabilistic EOR Screening Method to Integrate Theoretical Screening Criteria and Real Field EOR Practices Using Machine Learning Algorithms," in SPE Russian Petroleum Technology Conference, 2015.

[11] C. K. Morooka, I. R. Guilherme, and J. R. P. Mendes, "Development of intelligent systems for well drilling and petroleum production," J. Pet. Sci. Eng., vol. 32, no. 2-4, pp. 191-199, 2001.

[12] M. Nageh, M. A. El Ela, E. S. El Tayeb, and H. Sayyouh, "Application of Using Fuzzy Logic as an Artificial Intelligence Technique in the Screening Criteria of the EOR Technologies," in SPE North Africa Technical Conference and Exhibition, 2015.

[13] J. J. Taber, F. D. Martin, and R. S. Seright, "EOR screening criteria revisited-Part 1: Introduction to screening criteria and enhanced recovery field projects," SPE Reserv. Eng., vol. 12, no. 03, pp. 189-198, 1997.

[14] M. L. Trujillo Portillo et al., "Selection methodology for screening evaluation of enhancedoil-recovery methods," in SPE Latin American and Caribbean Petroleum Engineering Conference, 2010.

[15] Y. Wulandari, "Aplikasi metode mamdani dalam penentuan status gizi dengan Indeks Massa Tubuh (IMT) menggunakan logika fuzzy," Univ. Negeri Yogyakarta, Yogyakarta, Skripsi, 2011.

[16] W. J. Parkinson, "Screening EOR Methods with Fuzzy Logic," in International Reservoir Characterization Conference, Tulsa, Oklahoma, 1991, pp. 3-5.

[17] E. Prasetyo, "Data mining mengolah data menjadi informasi menggunakan matlab," Yogyakarta Andi Offset, 2014.

[18] L. D. Saleh, M. Wei, and B. Bai, "Data analysis and updated screening criteria for polymer flooding based on oilfield data," SPE Reserv. Eval. Eng., vol. 17, no. 01, pp. 15-25, 2014.

[19] H. M. Goda, K. A. Abdel Fattah, E. M. Shokir, and M. H. Sayyouh, "Neural network modeling approach for EOR method selection and evaluation," Nafta, vol. 53, no. 9, pp. 327-330, 2002.

[20] B. A. Suleimanov, F. S. Ismayilov, O. A. Dyshin, and E. F. Veliyev, "Selection methodology for screening evaluation of EOR methods," Pet. Sci. Technol., vol. 34, no. 10, pp. 961-970, 2016.

[21] M. Soleh, "Sistem Pakar Penentuan Selera Konsumen Terhadap Menu Kopi Dengan Metode Fuzzy Logic.” Semarang: Universitas Dian Nuswantoro, 2013. 


\section{BIOGRAPHY OF AUTHORS}

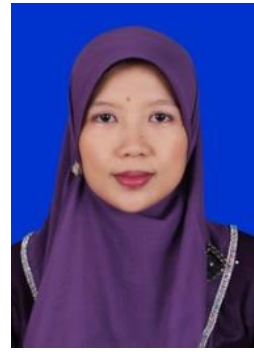

Nesi Syafitri obtained Bachelor Degree in Computer Science from UPI YPTK Padang in 2003, obtained Master Degree in Computer Science from Universitas Gadjah Mada in 2009. She has been a Lecturer with the Department of Informatics Engineering, Universitas Islam Riau, since 2011. His current research interests include computational linguistics, natural language processing and machine learning. 